\title{
Influence of the sowing depth and amount of sugarcane straw on the emergence of Chloris polydactyla and Eleusine indica and their control by herbicides applied pre-emergence
}

\section{Influência da profundidade de semeadura e da quantidade de palha de cana-de-açúcar na emergência de Chloris polydactyla e Eleusine indica e controle por herbicidas aplicados em pré-emergência}

\author{
Marcelo Rafael Malardo ${ }^{1}$; Patrícia Andrea Monquero ${ }^{2 *}$; \\ Paulo Henrique Vieira dos Santos ${ }^{3}$; Nagilla Moraes Ribeiro ${ }^{3}$; \\ Paulo Vinicius da Silva ${ }^{4}$; Andreia Cristina Silva Hirata ${ }^{5}$
}

\begin{abstract}
The objective of this study was to evaluate the effect of the sowing depth and amount of sugarcane straw on the soil on the emergence of Chloris polydactyla ('capim-branco') and Eleusine indica (Indian goosegrass) and to determine the efficacy of herbicides applied pre-emergence in the control of these species under different straw amount and rainfall regime conditions. The experiments were conducted in a completely randomized design with four replications. In the first experiment, the effects of six sowing depths $(0.5,1,2,4,8$, and $10 \mathrm{~cm})$ and six sugarcane straw amounts $(0,1,2,4,8$ and $10 \mathrm{t}$ $\mathrm{ha}^{-1}$ ) were assessed on the emergence of Indian goosegrass and 'capim-branco' in a 6 x 6 factorial arrangement. In the second experiment, the efficacy in the control of these species was evaluated for one control without herbicide and five treatments (indaziflam, metribuzin, tebuthiuron, indaziflam + metribuzin, and indaziflam + tebuthiuron) applied pre-emergence over four straw amounts $(0,1,2$, and $\left.4 \mathrm{t} \mathrm{ha}^{-1}\right)$ in a $6 \times 4$ factorial arrangement. This experiment was evaluated under two rainfall regimes in separate experiments (simulation of $20 \mathrm{~mm}$ of rainfall 1 or 10 days after herbicide application). The 'capim-branco' showed a marked reduction in emergence beginning at $2 \mathrm{t} \mathrm{ha}^{-1}$ of straw and a $2 \mathrm{~cm}$ sowing depth. For the Indian goosegrass, the decline in emergence mainly occurred beginning at $4 \mathrm{tha}^{-1}$ of straw and a $4 \mathrm{~cm}$ sowing depth. Only some of the Indian goosegrass plants emerged at the greater sowing depths $(8$ and $10 \mathrm{~cm})$ and straw amounts $\left(8\right.$ and $\left.10 \mathrm{tha}^{-1}\right)$, whereas no emergence of the "capimbranco' was observed under these conditions. The treatments with sowing at a $1 \mathrm{~cm}$ depth and with 0 , 1,2 , and $4 \mathrm{tha}^{-1}$ of straw provided the highest emergence percentage for the species. Application of the herbicide indaziflam alone was the only ineffective treatment for the control of the weeds regardless of the amount of straw and the water regime used. We concluded that the increase in the sowing depth and the amount of straw significantly reduced the emergence of the species and that the presence of straw and the dry period interfered with the herbicide efficacy.
\end{abstract}

Key words: Indian goosegrass. 'Capim-branco'. Sugarcane. Straw.

\footnotetext{
${ }^{1}$ Discente de Engenharia Agronômica, Centro de Ciências Agrarias/UFSCar, Universidade Federal de São Carlos, UFSCAR, Araras, SP, Brasil. Bolsista FAPESP. E-mail: marcelo.malardo@hotmail.com

${ }^{2}$ Profa, Departamento de Recursos Naturais e Proteção Ambiental/Centro de Ciências Agrárias/UFSCAR, Araras, SP, Brasil. E-mail: pamonque@hotmail.com

${ }^{3}$ Discentes, Engenharia Agronômica, Centro de Ciências Agrarias/UFSCar, UFSCAR, Araras, SP, Brasil. E-mail: castelly.sert@ hotmail.com; nagillamoraes@hotmail.com

${ }^{4}$ Discente de Doutorado, Produção Vegetal, Escola de Agricultura Luiz de Queiroz, ESALQ/USP, Piracicaba, SP, Brasil. E-mail: paulovsi@yahoo.com.br

${ }_{5}^{5}$ Pesquisadora em Produção Vegetal, Agência Paulista de Tecnologia e Agronegócios, Pólo da Alta Sorocabana, Presidente Prudente, SP, Brasil. E-mail: andreiacs@apta.sp.gov.br

* Author for correspondence
} 


\title{
Resumo
}

\begin{abstract}
Objetivou-se com esse trabalho avaliar o efeito da profundidade de semeadura e da quantidade de palha de cana-de-açúcar sobre o solo na emergência de Chloris polydactyla (capim-branco) e Eleusine indica (capim pé-de-galinha), assim como determinar a eficácia de herbicidas aplicados em pré-emergência no controle dessas espécies, sob diferentes quantidades de palha e regimes de precipitação pluvial. Os experimentos foram realizados no delineamento inteiramente casualizado, com quatro repetições. No primeiro experimento foram avaliadas seis profundidades de semeadura $(0,5 ; 1 ; 2 ; 4 ; 8$ e $10 \mathrm{~cm})$ e seis quantidades de palha de cana-de-açúcar $\left(0 ; 1 ; 2 ; 4 ; 8\right.$ e 10 t ha $\left.^{-1}\right)$ na emergência de capim pé-de-galinha e capim-branco, em esquema fatorial $6 \times 6$. No segundo experimento foi avaliada a eficácia de cinco tratamentos no controle dessas espécies: indaziflam, metribuzin, tebuthiuron, indaziflam + metribuzin e indaziflam + tebuthiuron e uma testemunha sem herbicida, aplicados em pré-emergência sobre quatro quantidades de palha $\left(0 ; 1 ; 2 \mathrm{e} 4 \mathrm{t} \mathrm{ha}^{-1}\right)$, em esquema fatorial $6 \times 4$. Este experimento foi avaliado sob dois regimes pluviais em experimentos separados (simulação de chuva de $20 \mathrm{~mm}$ a 1 ou 10 dias após a aplicação dos herbicidas). O capim-branco apresentou redução acentuada da emergência a partir de $2 \mathrm{t}$ ha $^{-1}$ de palha e $2 \mathrm{~cm}$ de profundidade de semeadura. Para o capim pé-de-galinha a queda na emergência ocorreu principalmente a partir de $4 \mathrm{t} \mathrm{ha}^{-1}$ de palha e $4 \mathrm{~cm}$ de profundidade de semeadura. Apenas algumas plantas do capim pé-de-galinha emergiram nas maiores profundidades de semeadura (8 e 10 $\mathrm{cm})$ e quantidades de palha $\left(8 \mathrm{e} 10 \mathrm{t} \mathrm{ha}^{-1}\right)$. Não houve emergência do capim-branco nessas condições. Os tratamentos com semeadura a $1 \mathrm{~cm}$ de profundidade e com $0,1,2 \mathrm{e} 4 \mathrm{t} \mathrm{ha}^{-1}$ foram os que proporcionaram a maior porcentagem de emergência das espécies. O herbicida indaziflam aplicado isoladamente foi o único tratamento ineficaz para o controle das plantas daninhas, independentemente da quantidade de palha e regime hídrico. Concluiu-se que o aumento da profundidade de semeadura e da quantidade de palha reduz significativamente a emergência das espécies, sendo que a presença de palha e o período seco interferem na eficácia dos herbicidas.
\end{abstract}

Palavras-chave: Capim pé-de-galinha. Capim-branco. Cana-de-açúcar. Palhada.

\section{Introduction}

Sugarcane straw deposited on the soil after mechanical harvesting can be a barrier to the germination and emergence of some weed species, as can the use of herbicides applied pre-emergence (SILVA; MONQUERO, 2013; NEGRISOLI et al., 2011). Straw kept on the soil surface affects the dormancy, germination, and mortality of weed seeds, causing changes in the weed community. However, these changes are very specific and dynamic because they depend on the amount of straw and especially on the weed species, which may be favored or not favored by the mulch (CORREIA; DURIGAN, 2004). Furthermore, the straw also intercepts the herbicides, making them vulnerable to volatilization and/or photolysis until they are leached into the soil, where they will have an effective action (LOCKE; BRYSON, 1997).

Together with the presence and amount of straw, we must consider the depth in the soil at which the seeds of each species are able to germinate and produce seedlings (KUVA et al., 2007). In sugarcane systems involving cane bundling or the removal of straw for bioenergy production, the amount of straw left on the soil is low and not uniform, which enables species that have small seeds (with a small amount of reserves) that are positively photoblastic (generally grasses) to germinate at shallow depths in the soil (CANOSSA et al., 2007).

Among the weed grasses in sugarcane plantations, an increase in the occurrence of Chloris polydactyla ('capim-branco') has been found in the access tracks and at the edges of stands. Reports have indicated difficulty in the control of this species in areas with high weed infestation and/or in an advanced stage of development (CARVALHO et al., 2005). This weed belongs to the Poaceae family, which is native to the American continent and has a wide geographic distribution; these weeds can propagate by seed and/or from rhizomes (KISSMANN, 1997). Little information on the control of 'capim-branco' 
is available. Currently, the biggest concern is the low susceptibility of 'capim-branco' to glyphosate, which has enabled this species to become a problem plant in areas with the recurrent use of this herbicide. This finding justifies the study of alternative herbicides to control this species (BARROSO et al., 2014).

Eleusine indica (Indian goosegrass), on the other hand, is one of the main weeds in sugarcane crops. Indian goosegrass has a competitive advantage in relation to other species under compacted soil conditions with low fertility and high acidity. The germination rate of the seeds is less than $10 \%$ when placed under constant temperatures between 20 and $35^{\circ} \mathrm{C}$; however, the rate rises to $99 \%$ under thermal fluctuation conditions (VIDAL et al., 2006). Indian goosegrass is spread throughout almost all of Brazil. This weed is an annual cycle species that belongs to the Poaceae family, is self-pollinating, reproduces by seeds (achene and free seeds), and can produce up to 40,000 seeds per plant (KISSMANN, 2007).

Among the herbicides used in sugarcane, a new product has been registered in Brazil called indaziflam. This product is an active ingredient with an herbicidal effect that belongs to the chemical group alkylazine and inhibits cellulose biosynthesis (TOMPKINS, 2010). No herbicide belonging to this chemical group has been registered for use in Brazil (AGROFIT, 2016). This herbicide controls monocots and eudicots during pre-emergence or early post-emergence (BROSNAN et al., 2011; PERRY et al., 2011; BROSNAN et al., 2012); however, it is more effective for the control of monocots (KAAPRO; HALL, 2012). Regarding its physicochemical characteristics, indaziflam has low solubility in water $\left(0.0028 \mathrm{~kg} \mathrm{~m}^{-3}\right.$ at $\left.20^{\circ} \mathrm{C}\right)$, a $\mathrm{K}_{\mathrm{oc}}<1,000 \mathrm{~mL} \mathrm{~g}^{-1}$ of organic carbon, a dissociation coefficient ( $\mathrm{pKa}$ ) of 3.5, an octanol-water partition coefficient $\left(\log \mathrm{K}_{\text {ow) }}\right.$ of 2.8 , and a vapor pressure of $5.1 \times 10^{-10} \mathrm{mmHg}$ at $25{ }^{\circ} \mathrm{C}$ (TOMPKINS, 2010). For the control of annual grasses, the doses oscillate from 25 to $100 \mathrm{~g} \mathrm{ha}^{-1}$ and can reach 150 $\mathrm{g} \mathrm{ha} \mathrm{h}^{-1}$ for more tolerant species (MYERS et al.,
2009; KAAPRO; HALL, 2012). Another important feature of indaziflam is its high residual period in the soil (more than 150 days); thus, this herbicide remains in the soil longer than other pre-emergent herbicides, which enables greater flexibility in the timing of its application (KAAPRO; HALL, 2012).

Two other herbicides registered for the sugarcane crop that are widely used in cane fields are metribuzin and tebuthiuron. Both herbicides act as inhibitors of photosynthesis in photosystem II by preventing the transport of electrons that accumulate at the inhibition point (QB protein), leading to lipid peroxidation (RODRIGUES; ALMEIDA, 2016).

Metribuzin, which belongs to the chemical group of triazinones and is recommended for application during the pre-emergence and early post-emergence of weeds, has a $\mathrm{K}_{\mathrm{oc}}$ value of $60 \mathrm{~mL}$ $\mathrm{g}^{-1}$, which indicates that this herbicide is moderately adsorbed in soils with a high level of organic matter, a solubility in water of $1100 \mathrm{mg} \mathrm{L}^{-1}$ at $20{ }^{\circ} \mathrm{C}$, a dissociation coefficient $(\mathrm{pKa})$ of 1 , which indicates that it is a weak base, an octanol-water partition coefficient $\left(\log \mathrm{K}_{\text {ow }}\right)$ of 44.7 , and a vapor pressure $<10^{-5} \mathrm{mmHg}$ at $20^{\circ} \mathrm{C}$ (RODRIGUES; ALMEIDA, 2016). Rossi et al. (2013) observed that the amount of metribuzin that transposed the different amounts of straw with simulation of $100 \mathrm{~mm}$ of accumulated rainfall was greater when applied over $5 \mathrm{t} \mathrm{ha}^{-1}$ of sugarcane straw and lower for larger amounts (10, 15 , and $20 \mathrm{tha}^{-1}$ ). The mean simulation of 20 to 30 $\mathrm{mm}$ of rainfall one day after the application of the herbicide was sufficient to promote a greater than $99 \%$ transposition of metribuzin.

Tebuthiuron, which belongs to the chemical group of the substituted ureas and is recommended for application during pre-emergence and early post-emergence, has a $\mathrm{K}_{\mathrm{oc}}$ value of $80 \mathrm{~mL} \mathrm{~g}^{-1}$, a water solubility of $2570 \mathrm{mg} \mathrm{L}^{-1}$ at $20{ }^{\circ} \mathrm{C}$, a nonapplicable dissociation coefficient $(\mathrm{pKa})$ because this herbicide is a non-ionizable molecule, an octanol-water partition coefficient $\left(\log \mathrm{K}_{\mathrm{ow}}\right.$ ) of 671 , and a vapor pressure of $2 \times 10^{-6} \mathrm{mmHg}$ at $20{ }^{\circ} \mathrm{C}$ 
(RODRIGUES; ALMEIDA, 2016). According to Tofoli et al. (2009), the longer tebuthiuron remains in the sugarcane straw before the occurrence of rain, the lower the total extraction of the product (even with $65 \mathrm{~mm}$ of rainfall); additionally, leaching of tebuthiuron into the soil decreased with the increase in the interval between the application and the first rainfall.

The use of herbicide combinations increases the efficiency and broadens the control spectrum. Each product has distinct physicochemical characteristics that establish distinct behaviors when applied in areas with straw, making crop management more efficient due to the reduction in the number of applications and the production costs (OLIVEIRA JÚNIOR, 2011). Additionally, knowledge of the dynamics of the germination and emergence of weeds at different soil depths is crucial for a better understanding of the constant changes and different results obtained by traditional control methods for weed management and the proposal of new management methods (GOMES JÚNIOR; CHRISTOFFOLETI, 2008).

Thus, the hypothesis of this work is that the sowing depth and the amount of sugarcane straw influence the emergence of $C$. polydactyla and $E$. indica and that different amounts of straw on the soil and water content after herbicide application can affect the action of the herbicides indaziflam, metribuzin, tebuthiuron and indaziflam and the combinations indaziflam + metribuzin and indaziflam + tebuthiuron in the control of these grasses.

\section{Materials and Methods}

Experiment 1. Effect of the sowing depth and amount of sugarcane straw on the soil on the emergence of Chloris polydactyla ('capim-branco') and Eleusine indica (Indian goosegrass)

The experiment was set up in a greenhouse with automatic irrigation, and the species were evaluated separately in a completely randomized experimental design with four replications. The treatments were arranged in a $6 \times 6$ factorial scheme with six sowing depths $(0.5,1,2,4,8$, and $10 \mathrm{~cm})$ and six straw amounts $\left(0,1,2,4,8\right.$, and $\left.10 \mathrm{tha}^{-1}\right)$.

The experimental units consisted of five-liter pots filled with sifted soil that had been removed from the arable layer $(0-20 \mathrm{~cm})$ of a dystrophic red latosol (Typic Haplorthox) (EMBRAPA, 2011) in an area without the presence of these weeds and without fertilization. The soil samples were subjected to chemical and physical analyses by the Laboratory for Soil Chemistry and Fertility (Table 1).

Table 1. Chemical analysis of the soil.

\begin{tabular}{cccccccccccccc}
\hline \multicolumn{10}{c}{} & \multicolumn{10}{c}{ Dystrophic red latosol } \\
\hline $\mathrm{P}$ & $\mathrm{OM}$. & $\mathrm{pH}$ & $\mathrm{K}$ & $\mathrm{Ca}$ & $\mathrm{Mg}$ & $\mathrm{H}+\mathrm{Al}$ & $\mathrm{Al}$ & $\mathrm{SB}$ & $\mathrm{CTC}$ & $\mathrm{V}$ & Clay & Sand & Silte \\
\hline $\mathrm{mg} \mathrm{dm}^{-3}$ & $\mathrm{~g} \mathrm{dm}^{-3}$ & $\mathrm{CaCl}_{2}$ & \multicolumn{2}{c}{$\mathrm{mmol}_{\mathrm{c}}$} & $\mathrm{dm}^{-3}$ & & $\%$ & & & $\%$ & & $\mathrm{~g} \mathrm{~kg}^{-1}$ & \\
\hline 15 & 24 & 5.1 & 2.5 & 28 & 12 & 40 & 0.4 & 42.5 & 82.5 & 52 & 660 & 150 & 190 \\
\hline
\end{tabular}

The 'capim-branco' and Indian goosegrass seeds were acquired from a company specializing in the production of weed seeds. The quantities of seeds used were $0.18 \mathrm{~g}$ (380 seeds) for 'capim-branco' and $0.5 \mathrm{~g}$ (110 seeds) for Indian goosegrass.

The sugarcane straw was taken from a commercial cane plantation where herbicides had not been applied and subsequently air dried, manually chopped, and then placed in the pots in the specified amounts after sowing the weeds.

For the distribution of the seeds at different depths $(0.5,1,2,4,8$, and $10 \mathrm{~cm})$, the interiors of the pots were marked with a correction pen (white ink) starting from the standard surface $(0 \mathrm{~cm})$, 
and the different depths were marked to guide the sowing. Immediately after sowing, the straw was placed on the soil surface in the amounts specified for the treatments.

The emergence of the grasses was evaluated weekly until 42 days after sowing (DAS) by counting the number of emerged plants. The total data for seedling emergence in the last evaluation were transformed into percentages based on the total number of seeds initially placed in the pots. The emergence rate index (ERI) was also calculated using the following formula proposed by Maguire (1962): $\mathrm{ERI}=\mathrm{N} 1 / \mathrm{D} 1+\mathrm{N} 2 / \mathrm{D} 2+\ldots+\mathrm{Nn} / \mathrm{Dn}$, in which ERI = emergence rate index, $\mathrm{N}=$ number of emerged seedlings on the day of counting, and $\mathrm{D}=$ number of days after sowing at which the counting was conducted.

The data for the emergence percentage and ERI were subjected to analysis of variance, and the significant mean values were subjected to a regression analysis using the SigmaPlot program.

Experiment 2. Control of C. polydactyla and E. indica by the herbicides indaziflam, metribuzin, tebuthiuron, indaziflam + metribuzin, and indaziflam + tebuthiuron as a function of different amounts of sugarcane straw on the soil and rainfall simulation after application

The experiment was conducted in a greenhouse in a completely randomized design. An experiment was performed for each rainfall simulation interval in a 6 x 4 factorial arrangement with four replications. Six treatments were evaluated (indaziflam, metribuzin, tebuthiuron, indaziflam + metribuzin, indaziflam + tebuthiuron, and a control with no use of herbicide) together with four amounts of sugarcane straw $(0$, 1,2 , and $4 \mathrm{t} \mathrm{ha}^{-1}$ ) on the soil. These straw amounts were selected based on the first experiment due to the higher emergence rates of the weeds.

The experimental units consisted of five-liter pots filled with sifted soil that had been removed from the arable layer $(0-20 \mathrm{~cm})$ of a dystrophic red latosol (EMBRAPA, 2011), whose analysis is presented in Table 1.

The weeds were evaluated separately and sown at a depth of $1 \mathrm{~cm}$ from the soil surface in the same quantities described for Experiment 1. Immediately after sowing, the pots were irrigated $(5 \mathrm{~mm}$ of water), and the sugarcane straw was deposited on the soil. The herbicides were applied the following day.

For the application of the herbicides indaziflam (75 $\mathrm{g}$ active ingredient (a.i.) ha $\left.{ }^{-1}\right)$, metribuzin (1920 g a.i. ha $\left.\mathrm{a}^{-1}\right)$, tebuthiuron $\left(1000 \mathrm{~g}\right.$ a.i. ha $\left.{ }^{-1}\right)$, indaziflam + metribuzin (75 g a.i. ha ${ }^{-1}+960$ g a.i. ha $\left.{ }^{-1}\right)$, and indaziflam + tebuthiuron $\left(75 \mathrm{~g}\right.$ a.i. $\mathrm{ha}^{-1}+500 \mathrm{~g}$ a.i. ha $^{-1}$ ), a $\mathrm{CO}_{2}$-pressurized backpack sprayer with 30 $\mathrm{lb}$ inch ${ }^{-2}$ pressure equipped with a boom fitted with four flat-fan nozzles (XR11003 model) spaced 0.5 $\mathrm{m}$ apart was used with consumption of $150 \mathrm{~L} \mathrm{ha}^{-1}$ of the spray mixture. The meteorological conditions at the time of application were a wind velocity of $0.6 \mathrm{~m} \mathrm{~s}^{-1}$, a relative humidity of $61.8 \%$, and an air temperature of $29.8^{\circ} \mathrm{C}$.

The pots were separated after the application of the herbicides. Half of the pots received $20 \mathrm{~mm}$ of water $\left(0.28 \mathrm{~mm} \mathrm{~min}^{-1}\right)$ one day after the application of the treatments and then continued to be irrigated via spraying to ensure seed germination. The other half of the pots were not irrigated until 10 days after application (DAA) when they received $20 \mathrm{~mm}$ of simulated rainfall, after which daily irrigation was performed.

At 42 days after sowing (DAS), the control percentage for the weeds was evaluated, and the shoot dry mass was obtained. The control percentage due to the herbicides was based on qualitative criteria in accordance with ALAM (1974) using a percentage rating scale in which zero (0) corresponded to no injury to the plant and one hundred (100) corresponded to death of the plant. To obtain the shoot dry mass, the plants were cut close to the ground, placed in paper bags, and later 
placed in a forced-air oven at $60{ }^{\circ} \mathrm{C}$ until a constant weight was obtained.

The data obtained for the percentage of the control and shoot dry mass were subjected to analysis of variance using the F-test; when significant, the data were analyzed by nonlinear regression using the SigmaPlot software.

\section{Results and Discussion}

Effect of the sowing depth and amount of sugarcane straw on the soil on the emergence of C. polydactyla ('capim-branco') and E. indica (Indian goosegrass)

A significant interaction was observed between the sowing depth and the amount of straw for the emergence percentages and the emergence rate indices (ERIs) of the 'capim-branco' (Figure 1) and Indian goosegrass (Figure 2). The emergence percentage of 'capim-branco' was low, with an estimated maximum value of $29.8 \%$ in the treatment without straw at depths of 1.2 and $1.3 \mathrm{~cm}$. A study of the $R$. cochinchinensis species showed that the emergence of the plants was higher when the seeds were sown on the soil surface, whereas the emergence decreased with the increase in the sowing depth, with no emerged plants observed after a depth of $10 \mathrm{~cm}$ (BOLFREY-ARKU et al., 2011). The increase in the amount of straw had a negative effect on the emergence of 'capim-branco', and this effect was enhanced by the increase in the depth. At a depth of $2 \mathrm{~cm}$, emergence was observed with up to 2 tha $^{-1}$ of straw; however, emergence was practically absent from $4 \mathrm{t} \mathrm{ha}^{-1}$ onward, with only a few plants emerging. With the increase in the amount of straw, a significant decrease was observed in the emergence at all depths; with $10 \mathrm{t} \mathrm{ha}^{-1}$, no plants were observed at any of the sowing depths. When analyzing the sowing depth $\mathrm{x}$ sugarcane straw interaction in the emergence of Rottboellia exaltata, Correia et al. (2013) also observed that the presence of plants decreased linearly with the increase in the amount of straw on the soil at all of the sowing depths studied with the exception of surface sowing. In the present study, the treatment involving sowing at a depth of $0.5 \mathrm{~cm}$ with $0 \mathrm{t} \mathrm{ha}^{-1}$ of straw led to less emergence than sowing at $1 \mathrm{~cm}$ with the same amount of straw, which was probably due to the greater exposure of the seeds to temperature and humidity variations (Figure 1).

The ERIs of 'capim-branco' followed the same trend as the emergence percentages. Excess straw combined with increased depth reduced the emergence rate of the plants. At greater depths, the seedling has to travel a greater distance, and the straw is an obstacle that hinders the seedling's movement up to the surface of the soil. The higher ERI is important because rapid emergence positively correlates with the space occupied and exploited by the plants and in turn determines the level of resources available for the growth and development of the plants (O'DONOVAN et al., 2000), which consequently affects the interference relationships between the weed and the crop.

For the Indian goosegrass, the increase in the amount of straw and the sowing depth also had a negative impact on the emergence of the plants (Figure 2). The highest emergence rate (38.7\%) was estimated in the treatment without straw combined with the $2.0 \mathrm{~cm}$ depth. At this depth, the treatment with $2 \mathrm{t} \mathrm{ha}^{-1}$ of straw led to $31.9 \%$ emergence. The treatments that resulted in a higher emergence rate were estimated to be those with depths between 1 and $3 \mathrm{~cm}$ sequentially combined with 0,1 , and $2 \mathrm{t}$ $\mathrm{ha}^{-1}$ of sugarcane straw. This result can be attributed to the physical effect of the mulch on the survival of the seedlings, especially for species with small levels of reserves in the seeds that may not be sufficient to guarantee the survival of the seedling in the space travelled within the mulch until it has access to light and starts the photosynthesis process (MONQUERO et al., 2012). These results corroborate those of Pacheco et al. (2009), in which Indian goosegrass plants sown at depths of 10 and $15 \mathrm{~cm}$ did not germinate; this finding was justified by the small seed size of this species. 
Figure 1. Percentage and emergence rate index (ERI) of C. polydactyla as a function of the sowing depth $(\mathrm{cm})$ and the amount of sugarcane straw $\left(\mathrm{t} \mathrm{ha}^{-1}\right)$ on the soil surface.

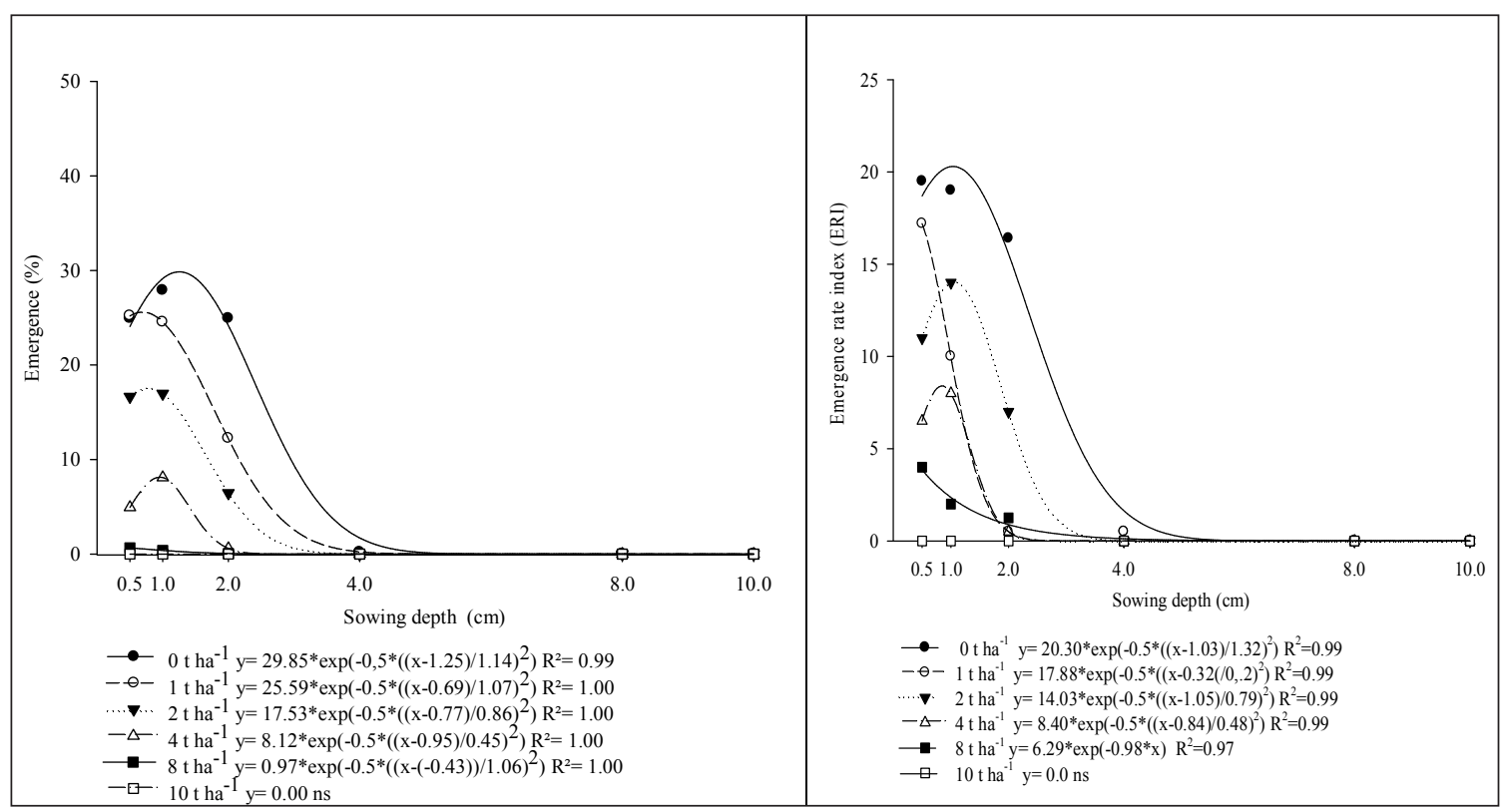

Figure 2. Percentage and emergence rate index (ERI) of E. indica as a function of the sowing depth (cm) and the amount of sugarcane straw $\left(\mathrm{t} \mathrm{ha}^{-1}\right)$ on the soil surface.

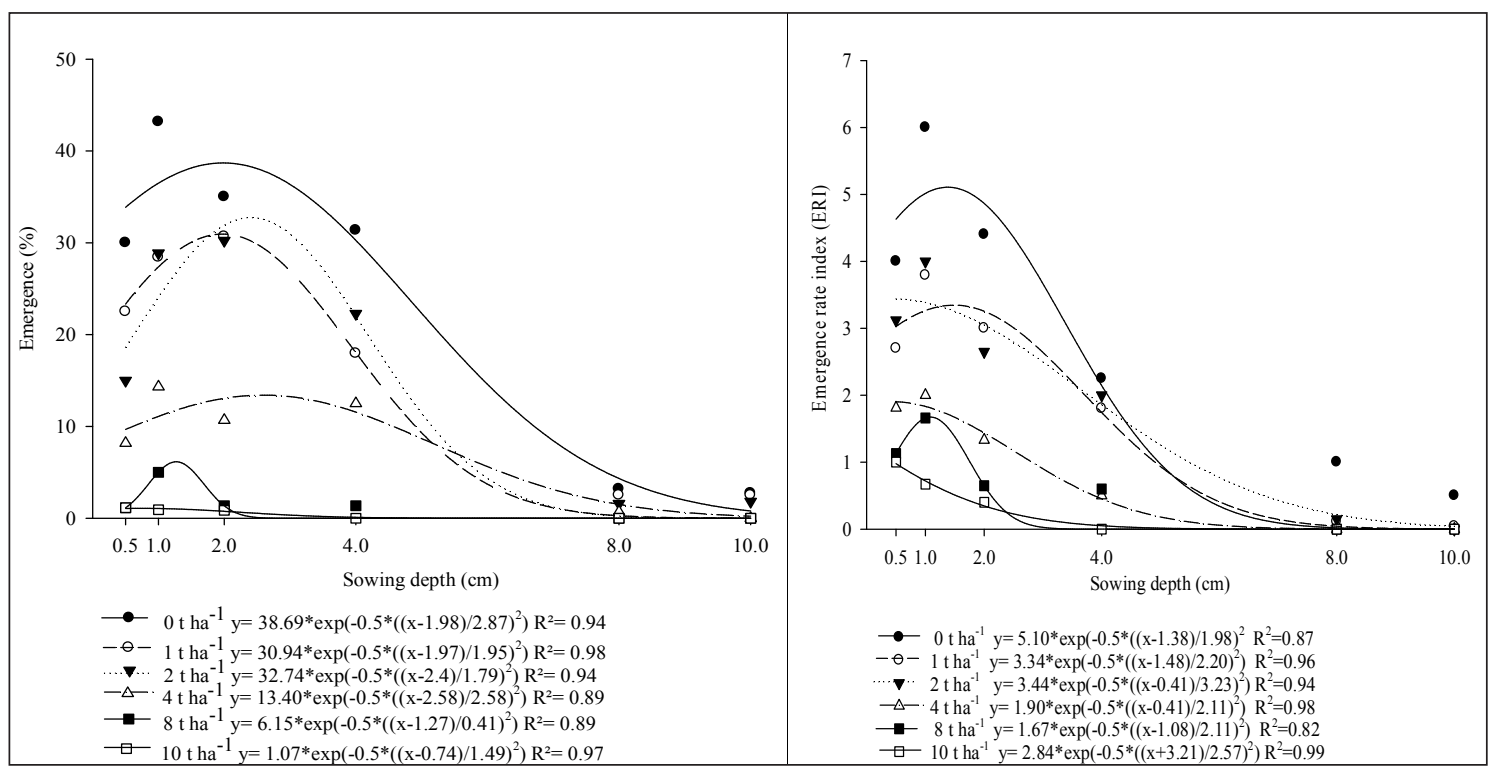

The behavior of the Indian goosegrass for the ERI was similar to that for the emergence rate, with faster emergence observed in the treatments without straw on the soil, followed by 1 and $2 \mathrm{tha}^{-1}$ of straw. The greater sowing depths had a negative impact on the ERI of the Indian goosegrass (Figure 2). Many weed species, especially those that have seeds with lower levels of reserves (e.g., grasses), germinate when placed closer to the surface of the soil because, in most cases, they require light to germinate. The presence of straw on the soil surface can also influence the emergence of many species because these plant residues alter the water content, luminosity, and temperature of the soil and have 
a potential allelopathic effect (LABONIA et al., 2009).

According to Yamauti et al. (2011), the position of the Indian goosegrass seeds (below, between, or on the sugarcane straw) did not affect the dry mass and the emergence of the plants; however, a decrease in the dry mass and the number of emerged plants was observed with the increase in the amount of straw above $8 \mathrm{t} \mathrm{ha}^{-1}$, which confirmed the results obtained in this present study.

In the work conducted by Correia and Durigan (2004) with Brachiaria decumbens and Sida spinosa, covering of the soil with sugarcane straw inhibited seedling emergence, but no significant difference was found between the 5,10 , and $15 \mathrm{t}$ $\mathrm{ha}^{-1}$ amounts. The same finding was observed for Digitaria horizontalis subjected to 10 and $15 \mathrm{tha}^{-1}$ of sugarcane straw. This result shows that species exhibit distinct abilities to emerge under different amounts of straw, given that the species studied in this work were negatively impacted in terms of emergence, even for low amounts of straw.

Germination is a key process in the organization and dynamics of plant species and is very sensitive to the soil coverage. Crop residues on the soil surface alter the water content, luminosity, and temperature of the soil, which are the main variables involved in the control of dormancy and germination of seeds. The coverage can also negatively affect the developing seedlings due to the physical barrier, which causes etiolation of the seedlings and makes them susceptible to mechanical damage (CORREIA; DURIGAN, 2004).

The physical effect of the mulch is very important for the regulation of germination and emergence and the survival of seedlings of some weed species. Among the effects, we should note the reduction in the germination of positively photoblastic seeds, which require a light stimulus to initiate germination, and the germination of seeds that need a wide range of thermal variation to inhibit the germination process. The physical effects of the straw also reduce the survival chances of seedlings with small levels of reserves in the diaspora (PITELLI; DURIGAN, 2001).

In the treatment with $8 \mathrm{t} \mathrm{ha}^{-1}$ of straw, some 'capim-branco' plants that passed through the straw layer had a chlorotic appearance and etiolated growth. For the Indian goosegrass, the plants from the treatments with sowing at the 4 and $8 \mathrm{~cm}$ depths combined with higher amounts of straw at the surface showed etiolation and thin leaves. The plants from the treatment with sowing at a $10 \mathrm{~cm}$ depth exhibited growth inhibition until the time of assessment (42 DAS) and did not totally pass through the straw layer.

The results indicated that sowing at a depth of $1 \mathrm{~cm}$ combined with $0,1,2$, and $4 \mathrm{t} \mathrm{ha}^{-1}$ of straw on the soil surface enabled the emergence of the weed species 'capim-branco' and Indian goosegrass despite the reduction in emergence with the increase in the amount of straw. Some Indian goosegrass plants showed an ability to emerge at a $10 \mathrm{~cm}$ depth. With surface sowing, some plants passed through $10 \mathrm{t} \mathrm{ha}^{-1}$ of straw; however, 'capim-branco' did not emerge at sowing depths greater than $8 \mathrm{~cm}$ and with amounts of straw in excess of $8 \mathrm{tha}^{-1}$.

Control of C. polydactyla and E. indica by the herbicides indaziflam, metribuzin, tebuthiuron, indaziflam + metribuzin, and indaziflam + tebuthiuron as a function of the different amounts of sugarcane straw on the soil and the rainfall interval after application

Sowing of the species at a $1 \mathrm{~cm}$ depth combined with $0,1,2$, and $4 \mathrm{tha}^{-1}$ of sugarcane straw was selected for the evaluation of the efficacy of herbicides applied pre-emergence with simulation of $20 \mathrm{~mm}$ of rainfall at 1 and $10 \mathrm{DAA}$. For the two species and rainfall simulations, a significant interaction was observed between the herbicides and the amounts of straw for the evaluated variables.

In the simulation of $20 \mathrm{~mm}$ of rainfall one day after the application of the herbicides on 'capimbranco', the combinations indaziflam + metribuzin 
and indaziflam + tebuthiuron and the herbicides metribuzin and tebuthiuron alone resulted in excellent control (equal to or close to $100 \%$ ) of this species for the four amounts of straw studied (Figure 3). The herbicide indaziflam alone was not effective in the control of 'capim-branco', with a control percentage ranging from $40 \%\left(4 \mathrm{tha}^{-1}\right)$ to approximately $60 \%\left(0 \mathrm{t} \mathrm{ha}^{-1}\right)$; thus, we observed a tendency toward a reduction in control as the amount of sugarcane straw on the soil increased. Regarding the shoot dry mass, the treatments with indaziflam + tebuthiuron and metribuzin controlled all of the plants, resulting in no dry mass production. The herbicide indaziflam alone was not effective in the control, leading to a dry mass accumulation similar to the control for all amounts of straw. The treatments with indaziflam + metribuzin and with tebuthiuron led to high control percentages and low percentage of dry mass values, with mean values among the amounts of straw of 1.20 and $8.32 \%$ shoot dry mass compared to the control (Figure 3).

With the simulation of $20 \mathrm{~mm}$ of rainfall at 10 DAA, the treatments with indaziflam + tebuthiuron and with metribuzin and tebuthiuron alone resulted in larger control percentages for this species; in some cases, the control was $100 \%$ (Figure 4). For these herbicides, no difference was observed for the amounts of sugarcane straw on the soil. The combination of indaziflam with metribuzin resulted in control of $72 \%$ in the treatment with $0 \mathrm{t} \mathrm{ha}^{-1}$ of straw, which gradually increased with the increase in the straw on the soil and culminated at $87.50 \%$. The herbicide indaziflam alone led to a mean control percentage of $66.75 \%$, which was below the minimum for registration purposes $(80 \%)$, and no difference was observed between the treatments based on the amount of straw.

These results from the combinations of indaziflam with metribuzin or tebuthiuron corroborate the results from previous studies involving the control of weed species of the Liliopsida and Magnoliopsida classes, which suggests that indaziflam should be combined with other residual herbicides to broaden the spectrum of action and control percentage (KAAPRO; HALL, 2012; JHALA; SINGH, 2012).

Figure 3. Percentages of the control and shoot dry mass (relative to the control) of the C. polydactyla plants as a function of the application of herbicides and the amount of sugarcane straw on the soil with the simulation of $20 \mathrm{~mm}$ of rainfall one day after application.

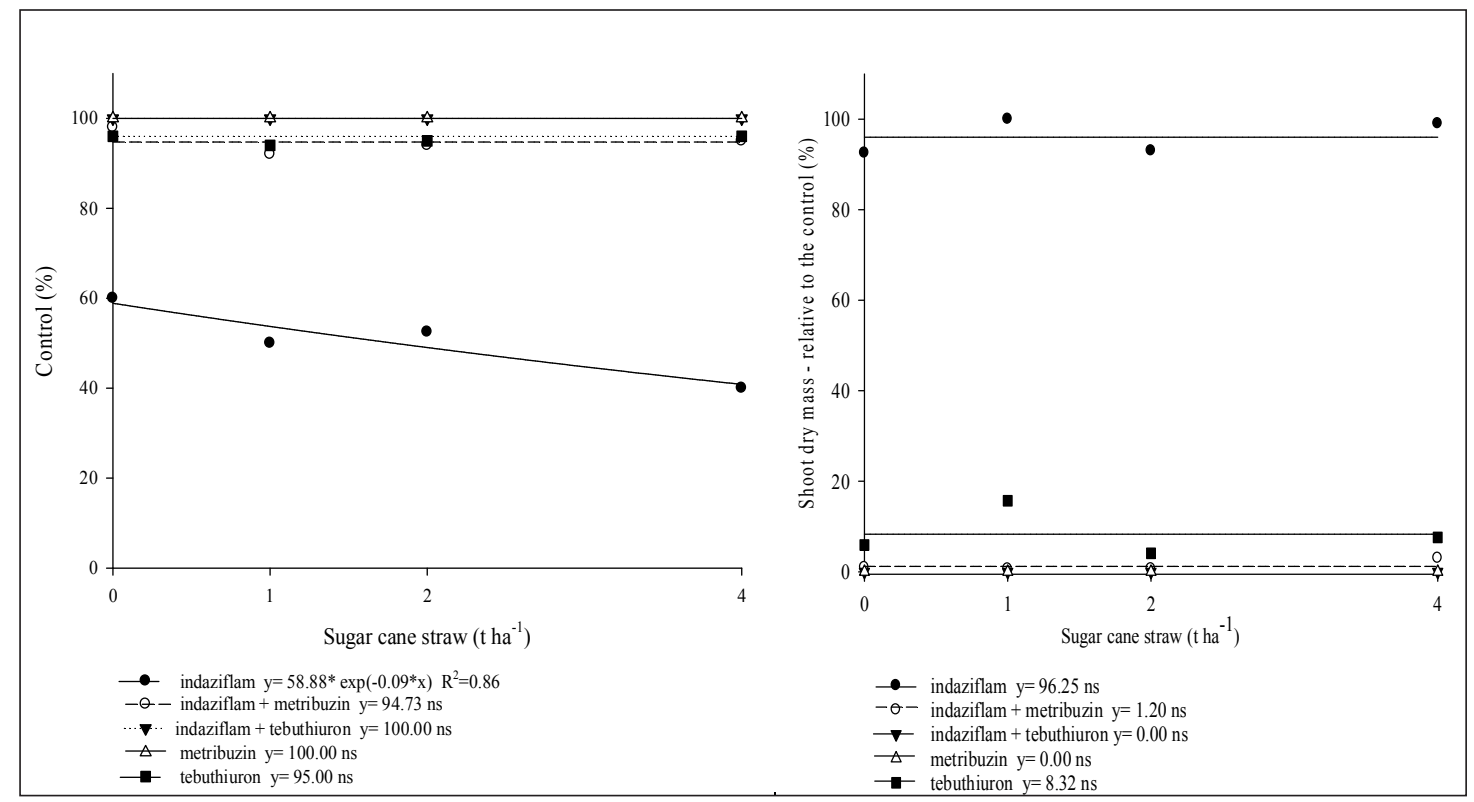


Figure 4. Percentages of the control and shoot dry mass (relative to the control) of the C. polydactyla plants as a function of the application of herbicides and the amount of sugarcane straw on the soil with the simulation of $20 \mathrm{~mm}$ of rainfall at 10 DAA.

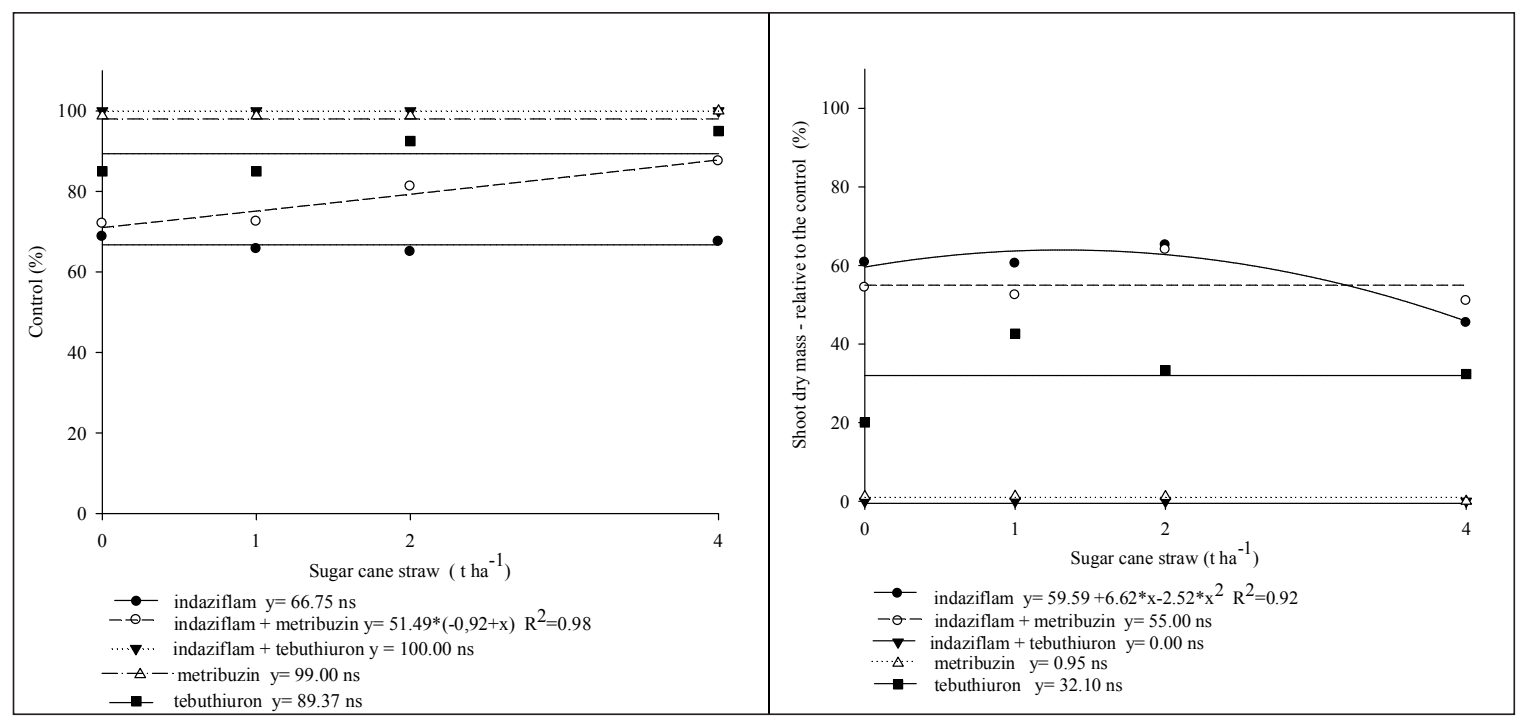

Regarding the percentage of shoot dry mass, the treatments with indaziflam + tebuthiuron and metribuzin led to a lower dry mass accumulation. The treatment with tebuthiuron resulted in a mean dry mass percentage of $32.10 \%$ relative to the control. The treatments with indaziflam and the combination indaziflam + metribuzin led to the highest percentages of dry mass relative to the control; in the treatment with indaziflam, the dry mass of 'capim-branco' ranged from approximately $60 \%$ in the absence of sugarcane straw on the soil to $45 \%$ with the presence of $4 \mathrm{tha}^{-1}$ of straw on the soil surface based on the regression equation. Treatment with the indaziflam + metribuzin combination showed no differences for the different amounts of straw on the soil surface, with a mean dry mass value of $55 \%$ relative to the control (Figure 4).

Regarding the control percentage of the Indian goosegrass, for the simulation of rainfall one day after the application of the herbicides, all of the herbicides and amounts of straw caused a high control percentage (above $80 \%$ ) with the exception of metribuzin alone, which was inefficient when applied directly to the soil. These results show the positive effect of the straw on the performance of this herbicide, which can be attributed to a possible reduction in the leaching rate (Figure 5). No effect of the presence of straw or the different amounts of straw on the performance of the herbicides was observed with the exception of metribuzin, for which the straw favored the action of the herbicide regardless of the amount.

Lower percentages of dry mass than the control were observed with the use of indaziflam + metribuzin and tebuthiuron; these herbicides caused the death of the plants regardless of the amount of straw used. In the treatments with indaziflam + tebuthiuron, and indaziflam alone, no differences were observed between the different amounts of straw, with mean values of 15.81 and $8.59 \%$ of the dry mass, respectively. The herbicide metribuzin also led to low dry mass values relative to the control; the highest estimated value (47\%) was found in the treatment with no straw on the soil surface, and a decline was seen as the amount of straw increased (Figure 5). 
Figure 5. Percentages of the control and shoot dry mass (relative to the control) of the E. indica plants as a function of the application of herbicides and the amount of sugarcane straw on the soil with the simulation of $20 \mathrm{~mm}$ of rainfall one day after application.

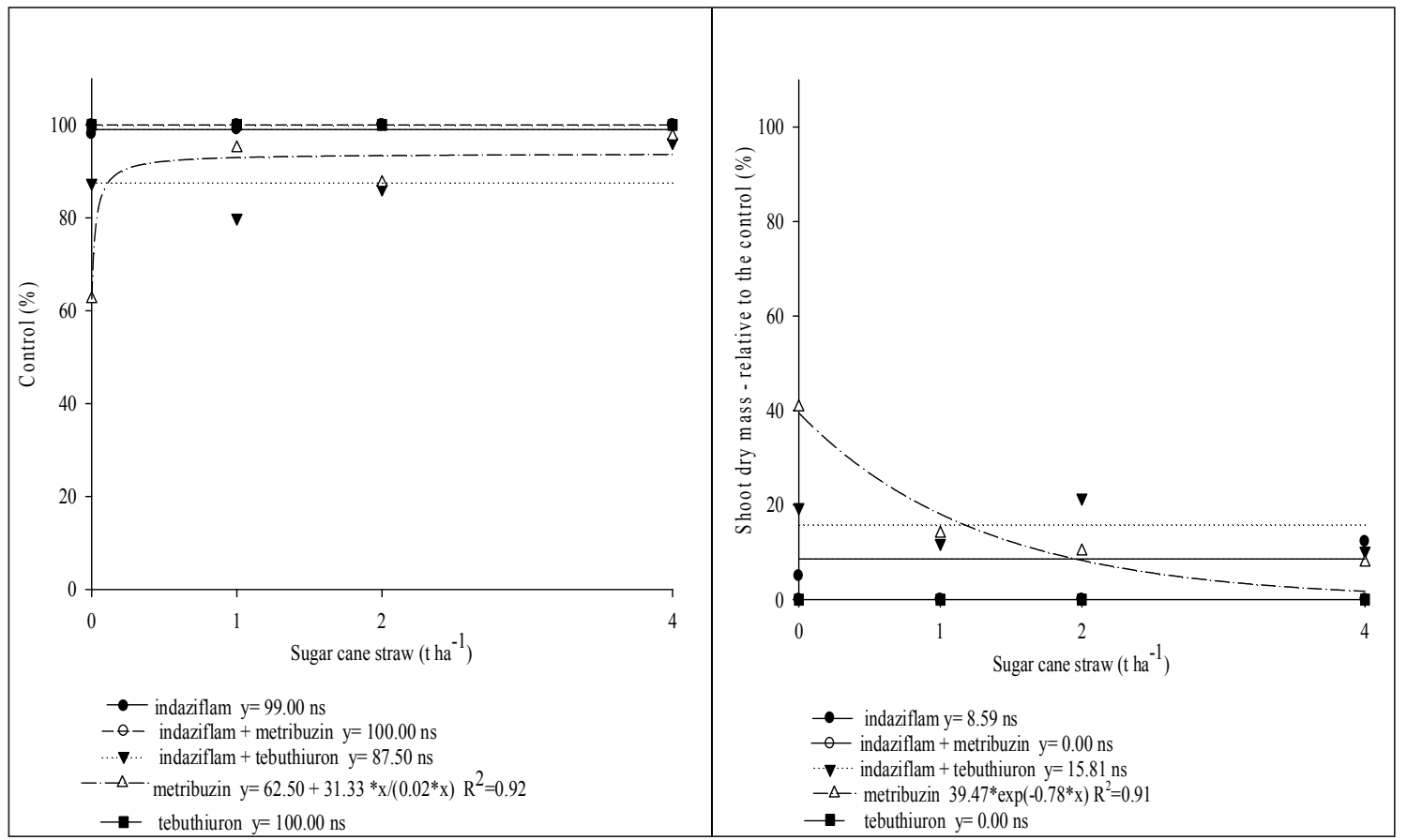

With the simulation of $20 \mathrm{~mm}$ of rainfall at 10 DAA, the indaziflam treatment alone led to a mean control percentage for the Indian goosegrass of $81.50 \%$, and no difference was observed between the amounts of sugarcane straw. The indaziflam + metribuzin combination was efficient in controlling the weed for all of the amounts of straw, similar to the use of tebuthiuron alone. An effect of the straw amount was observed for the indaziflam + tebuthiuron combination and for metribuzin alone, and an increase in the control was seen with the increase in the amount of straw, which could be a result of the synergism between the control by the herbicide and the physical and chemical effects of the straw. Thus, the combination of the straw with different herbicides may result in distinct control of the species (Figure 6).

Guerra et al. (2015) observed that the efficiency in the control of weeds by the herbicide indaziflam when applied on $10 \mathrm{tha}^{-1}$ of sugarcane straw on the soil was dependent on the occurrence of rainfall shortly after the application. These results are similar to those found by Rossi et al. (2013) with the herbicide metribuzin, where greater transposition of the herbicide from the sugarcane straw $(5,10$, 15 , and $20 \mathrm{tha}^{-1}$ ) to the soil was observed when the rainfall simulation was performed on the same day as the herbicide application.

Regarding the results obtained with the use of tebuthiuron, Tofoli et al. (2009) showed that almost total interception of the applied herbicide occurred only in amounts of sugarcane straw greater than $5 \mathrm{t}$ $\mathrm{ha}^{-1}$, with transpositions of tebuthiuron at the time of application of less than $10 \%$ of the amount of product applied. These authors also noted that the first rainfall and the first $20 \mathrm{~mm}$ of rainfall were key for the leaching of tebuthiuron into the soil. 
Figure 6. Percentages of the control and shoot dry mass (relative to the control) of the E. indica plants as a function of the application of herbicides and the amount of sugarcane straw on the soil with the simulation of $20 \mathrm{~mm}$ of rainfall at 10 DAA.

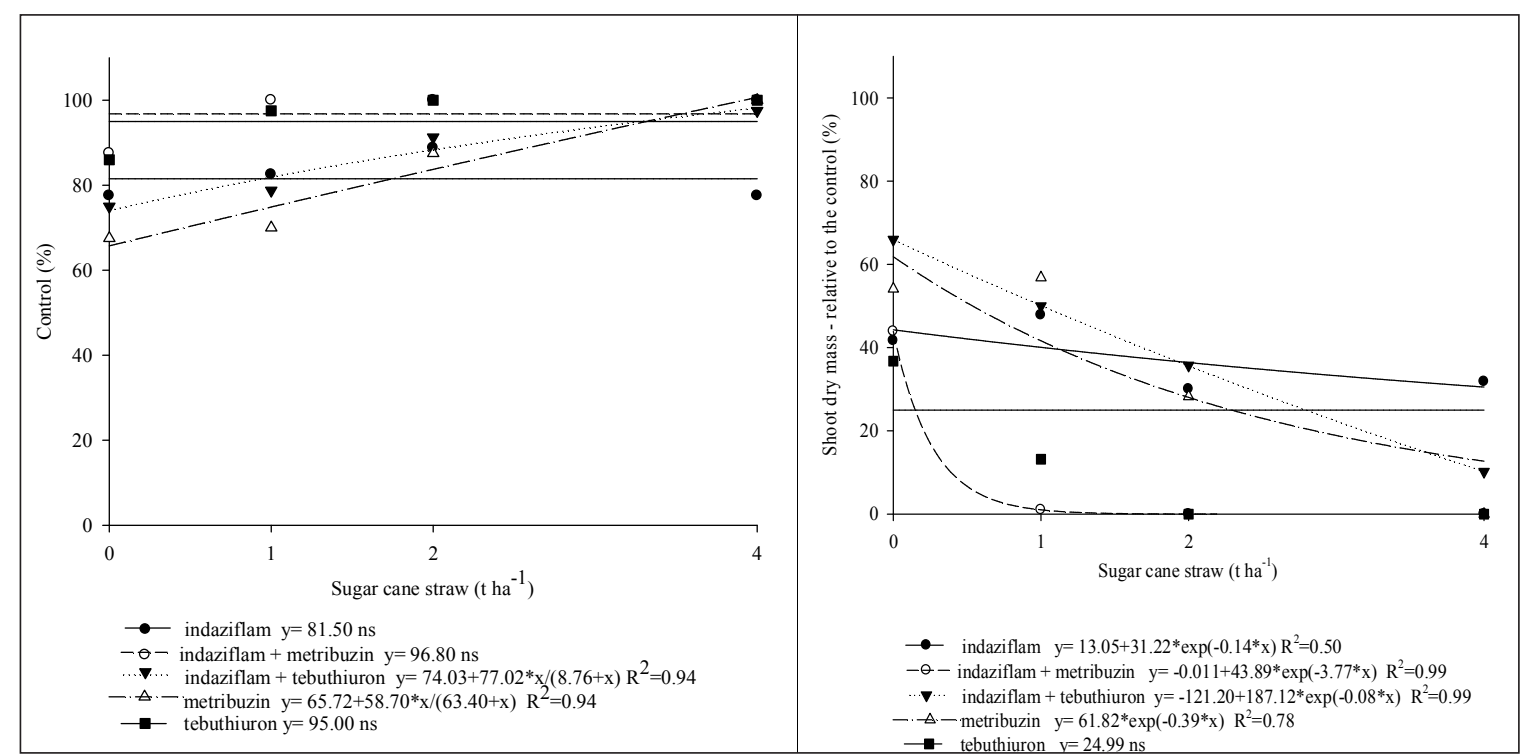

For the percentage of dry mass of the Indian goosegrass, all of the treatments resulted in a reduction in this variable with an increase in the amount of straw on the soil, especially indaziflam + metribuzin. The exception was the herbicide tebuthiuron, which showed no difference among the amounts of sugarcane straw on the soil, with an average of $24.99 \%$ of dry mass relative to the control (Figure 6).

The decreased efficacy when subjected to a longer dry period (simulation of $20 \mathrm{~mm}$ of rainfall at 10 DAA) could be explained by the longer time that the product was on the straw or on the soil surface without the presence of water. To exert their actions on the weeds, the residual herbicides need to be introduced directly into the soil, which occurs through leaching by rain due to the solubility of the product. If rainfall occurs immediately after spraying, the efficiency of the residual herbicide applied on the sugarcane straw will be dependent on the amount leached in this layer of straw (NEGRISOLI et al., 2007).

\section{Conclusion}

The increase in the sowing depth and the amount of sugarcane straw on the soil surface had a negative influence on the emergence and the ERI of Indian goosegrass and 'capim-branco'.

The 'capim-branco' showed a marked reduction in emergence beginning at $2 \mathrm{t} \mathrm{ha}^{-1}$ and a sowing depth of $2 \mathrm{~cm}$, whereas the Indian goosegrass showed a decline in emergence mainly beginning at $4 \mathrm{tha}^{-1}$ and a sowing depth of $4 \mathrm{~cm}$.

Variation was observed in the control of the Indian goosegrass and 'capim-branco' with the evaluated herbicides according to the amount of straw and the length of the dry period.

Application of the herbicide indaziflam alone was the only treatment that was ineffective for the control of the weeds regardless of the amount of straw and the water regime. 


\section{References}

ASOCIATION LATINOAMERICANA DE MALEZAS - ALAM. Recomendaciones sobre unificación de los sistemas de evaluación em ensayos de control de malezas. ALAM, Bogotá, v. 1, n. 1, p. 35-38, 1974.

BARROSO, A. A. M.; ALBRECHT, A. J. P.; REIS, F. C.; PLACIDO, H. F.; TOLEDO, R. E.; ALBRECHT, L. P.; VICTORIA FILHO, R. Different glyphosate susceptibility in Chloris polydactyla accessions. Weed Technology, Lawrence, v. 28, n. 4, p. 587-591, 2014.

BOLFREY-ARKU, G. E. K.; CHAUHAN, B. S.; JOHNSON, D. E. Seed germination ecology of itch grass (Rottboellia cochinchinensis). Weed Science, Lawrence, v. 59, n. 2, p. 182-187, 2011.

BROSNAN, J. T.; BREEDEN, G. K.; MCCULLOUGH, P. E.; HENRY, G. M. PRE and POST control of annual bluegrass (Роа апnиа) with indaziflam. Weed Technology, Champaign, v. 26, n. 1, p. 48-53, 2012.

BROSNAN, J. T.; MCCULLOUGH, P. E.; BREEDEN, G. K. Smooth crabgrass control with indaziflam at various spring timings. Weed Technology, Lawrence, v. 25, n. 3, p. 363-366, 2011.

CANOSSA, R. S.; OLIVEIRA JÚNIOR, R. S.; CONSTANTIN, J.; BIFFE, D. F.; ALONSO, D. G.; FRANCHINI, L. H. M. Profundidade de semeadura afetando a emergência de plântulas de Alternathera tenella. Plantas Daninhas, Viçosa, MG, v. 25, n. 4, p. 719-725, 2007.

CARVALHO, S. J. P.; PEREIRA SILVA, R. F.; LÓPEZOVEJERO, R. F.; NICOLAI, M.; CHRISTOFFOLETI, P. J. Crescimento, desenvolvimento e produção de sementes da planta capim-branco (Chloris polydactyla). Planta Daninha, Viçosa, MG, v. 23, n. 4, p. 603-609, 2005.

CORREIA, N. M.; DURIGAN, J. C. Emergência de plantas daninhas em solo coberto com palha de cana-deaçúcar. Planta Daninha, Viçosa, MG, v. 22, n.1, p. 11-17, 2004.

CORREIA, N. M.; GOMES, L. P.; PERUSSI, F. J. Emergência de Rottboellia exaltata influenciada pela profundidade de semeadura, quantidade de palha de cana sobre o solo e aplicação de herbicidas residuais. Acta Scientiarum Agronomy, Maringá, v. 35, n. 2, p. 145-152, 2013.

EMPRESA BRASILEIRA DE PESQUISA AGROPECUÁRIA - EMBRAPA. Manual de métodos de análise de solos. 2. ed. Rio de Janeiro: SNLCS, 2011. $225 \mathrm{p}$.
GOMES JÚNIOR, F. G.; CHRISTOFFOLETI, P. J. Biologia e manejo de plantas daninhas em áreas de plantio direto. Planta Daninha, Viçosa, MG, v. 26, n. 3, p. 789-798, 2008.

GUERRA, N.; OLIVEIRA JÚNIOR, R. S.; CONSTANTIN, J.; OLIVEIRA NETO, A. M.; PUTON, G.; GARRIDO, T. H. P. Influence of precipitation and sugarcane straw in aminocyclopyrachlor and indaziflam control efficiency. Planta Daninha, Viçosa, MG, v. 33, n. 3, p. 535-542, 2015.

JHALA, A. J.; SINGH. M. Leaching of indaziflam compared with residual herbicides commonly used in Florida citrus. Weed Technology, Lawrence, v. 26, n. 3, p. 602-607, 2012.

KAAPRO, J.; HALL, J. Indaziflam - a new herbicide for pre-emergent control of weeds in turf, forestry, industrial vegetation and ornamentals. Weed Science, Lawrence, v. 18, n. 2, p. 267-270, 2012.

KISSMANN, K. G. Plantas infestantes e nocivas. Tomo I. São Paulo: BASF, 1997. 825 p.

. Plantas infestantes e nocivas. Tomo I. 3. ed. São Paulo: BASF, 2007. CD-ROM.

KUVA, M.; PITELLI, R. A.; SALGADO, T. P.; ALVES, P. L. C. A. Fitossociologia de comunidades de plantas daninhas em agroecossistema cana-crua. Planta Daninha, Viçosa, MG, v. 25, n. 3, p. 501-511, 2007.

LABONIA, V. D. S.; CARVALHO, S. J. P.; MONDO, V. H. V.; CHIOVATO, M. G.; VICTORIA FILHO, R. Emergência de plantas da família Convolvulaceae influenciada pela profundidade da semente no solo e cobertura com palha de cana-de-açúcar. Planta Daninha, Viçosa, MG, v. 27, p. 921-929, 2009. Número Especial.

LOCKE, M.A.; BRYSON, C.T. Herbicide-soil interaction in reduced tillage and plant residue management systems. Weed Science, Lawrence, v. 45, n. 3, p. 307-320, 1997.

MAGUIRE, J. D. Speed of germination-aid in selection and evaluation for seedling emergence and vigor. Crop Science, Madison, v. 2, n. 1, p. 176-177, 1962.

MONQUERO, P. A.; HIJANO, N.; ORZARI, I.; SABBAG, R. dos S.; SILVA HIRATA, A. C. Profundidade de semeadura, $\mathrm{pH}$, textura e manejo da cobertura do solo na emergência de plântulas de Rottboellia exaltata. Semina: Ciências Agrárias, Londrina, v. 33, p. 27992812, 2012. Suplemento 1.

MYERS, D. F.; HANRAHAN, J. M.; MONKE, L. B.; MUDGE, C.; OLSEN, A. P.; SMITH, J.; SPAK, D. Indaziflam/BCS AA170717 - a new herbicide for preemergent control of grasses and broadleaves in turf and ornamentals. In: SOUTH SOCIETY WEED SCIENCE 
ABSTRACTS, 62., 2009, Portland. Proceedings... Portland: SWSS, 2009. p. 393.

NEGRISOLI, E.; VELINI, E. D.; ROSSI, C. V. S.; CORREIA, T. M.; COSTA, A. G. F. Associação do herbicida tebuthiuron com a cobertura de palha no controle de plantas daninhas no sistema de cana-crua. Planta Daninha, Viçosa, MG, v. 25, n. 3, p. 612-628, 2007.

NEGRISOLI, E.; VELINI, E. D.; ROSSI, C. V. S.; CORREIA, T. M.; COSTA, A. G. F.; PERIM, L. Influência da palha e da simulação de chuva sobre a eficácia da mistura formulada clomazone + hexazinone no controle de plantas daninhas em área de cana-crua. Planta Daninha, Viçosa, MG, v. 29, n. 1, p. 169-177, 2011.

O'DONOVAN, J. T.; HARKER, E.; CLAYTON, G. W.; HALL, L. M. Wild oat (Avena fatua) interference in barley (Hordeum vulgare) is influenced by barley variety and seeding rate. Weed Technology, Lawrence, v. 14, n. 3, p. 624-629, 2000.

OLIVEIRA JÚNIOR, R. S. Mecanismos de ação de herbicidas. In: OLIVEIRA JÚNIOR, R. S.; CONSTANTIN, J.; INOUE, M. H. Biologia de manejo de plantas daninhas. 2. ed. Curitiba: Ominpax, 2011. p. 149-150.

PACHECO, L. P.; PIRES, F. R.; MONTEIRO, F. P.; PROCOPIO, S. O.; ASSIS, R. L.; PETTER, S. A. Emergência e crescimento de plantas de cobertura em função da profundidade de semeadura. Semina: Ciencias Agrárias, Londrina, v. 30, n. 2, p. 305-314, 2009.

PERRY, D. H.; MCELROY, J. S.; DOROH, M. C.; WALKER, R. H. Indaziflam utilization for controlling problematic turfgrass weeds. Applied Turfgrass Science, Madison, v. 8, n. 1, p. 1-8, 2011.

PITELLI, R. A.; DURIGAN, J. C. Ecologia das plantas daninhas no sistema plantio direto. In: ROSSELLO, R. D. Siembra directa en el cono sur. Montevideo: PROCISUR, 2001. p. 203-210.
RODRIGUES, B. N.; ALMEIDA, F. S. Guia de herbicidas. 6. ed. Londrina: IAPAR, 2016. 697 p.

ROSSI, C. V. S.; VELINI, E. D.; LUCHINI, L. C.; NEGRISOLI, E.; CORREA, M. R.; PIVETTA, J. P.; COSTA, A. G. F.; SILVA, F. M. L. Dinâmica do herbicida metribuzin aplicado sobre palha de cana-de-açúcar (Saccarum officinarum). Planta daninha, Viçosa, MG, v. 31, n. 1, p. 223-230, 2013.

SILVA, P. V.; MONQUERO, P. A. Influência da palha no controle químico de plantas daninhas no sistema de cana crua. Revista Brasileira de Herbicidas, Londrina, v. 12, n. 1, p. 94-103, 2013.

SISTEMAS DE AGROTÓXICOS FITOSSANITÁRIOS - AGROFIT. Consulta de ingrediente ativo. Ministério da Agricultura, Pecuária e Abastecimento - MAPA. Coordenação-Geral de Agrotóxicos e Afins/DFIA/DAS, Brasília: MAPA, 2016. Disponível em: <http://agrofit. agricultura.gov.br/agrofit_cons/principal_agrofit_cons $>$. Acesso em: 12 mar. 2016.

TOFOLI, G. R.; VELINI, E. D.; NEGRISOLI, E.; CAVENAGHI, A. L.; MARTINS, D. Dinâmica do tebuthiuron em palha de cana-de-açúcar. Planta Daninha, Viçosa, MG, v. 27, n. 4, p. 815-821, 2009.

TOMPKINS, J. Pesticide fact sheet: indaziflam. Environmental protection agency report. Washington: EPA, 2010. Disponível em: <http://www.epa.gov/ opp00001/chem search/reg actions/registration/fs PC080818_26-Jul-10.pdf $>$. Acesso em: 15 jan. 2016.

VIDAL, R. A.; PORTES, E. S.; LAMEGO, F. P.; TREZZI, M. M. Eleusine indica resistance to ACCase inhibitors. Planta Daninha, Viçosa, MG, v. 24, n. 1, p. 163-171, 2006.

YAMAUTI, M. S.; BARROSO, A. A. M.; GIANCOTTI, P. R. F.; SQUASSONI, V. L.; REVOLTI, L. T. M.; ALVES, P. L. C. A. Emergência de plantas daninhas em função da posição da semente e quantidade de palha de cana-de-açúcar. Scientia Agraria, Curitiba, v. 12, n. 2, p. 75-80, 2011. 